\title{
Effects of different levels of UV-B radiation on marine epilithic communities: a short-term microcosm study*
}

\author{
ROMAN A. DANILOV and NILS G. A. EKELUND \\ Department of Applied Science, Mid Sweden University, 87188 Härnösand, Sweden. E-mail: roman.danilov@tnv.mh.se
}

\begin{abstract}
SUMMARY: Epilithic communities from brackish coastal water of the east coast of Sweden were studied in order to reveal their responses to different levels of UV-B radiation. The experiment was conducted for seven days in an indoor microcosm system. The epilithic communities were exposed daily to different doses of UV-B radiation: 1,3,5 and 7 hours, respectively. The intensity of the UV-B radiation used was similar to that in natural environments. After seven days clear shifts both in species composition and community structure were observed. All species of diatoms showed negative correlation with enhanced levels of UV-B. On the other hand, abundance of cyanobacteria was positively correlated with enhanced levels of UV-B (Calothrix aeruginea, R=0.49; Oscillatoria amphibia, $\mathrm{R}=0.93$; Pseudanabaena mucicola, $\mathrm{R}=0.26$ ). Communities dominated by diatoms and green algae at the initial stage of the experiment did show a drastic decrease in diatom abundance under UV-B stress and finally became dominated by cyanobacteria. Among green algae the abundance of Cladophora sericea correlated positively $(\mathrm{R}=0.33)$ with enhanced exposure to $\mathrm{UV}-\mathrm{B}$, while Monoraphidium-species exhibited negative correlation to UV-B. Otherwise, no significant correlation between other green algae species identified and UV-B stress could be detected. We conclude that UV-B radiation, even at lower levels, is capable to induce severe changes to marine epilithic communities. The trends revealed in the present study predict a shift from communities dominated by diatoms and green algae to those dominated by cyanobacteria.
\end{abstract}

Key words: Ultraviolet-B, epilitic communities, brackish water, Baltic Sea.

\section{INTRODUCTION}

A great environmental problem recognised during recent years is ozone depletion and a following increase of penetrating ultraviolet-B radiation (UVB, 280-315 nm). It has been well documented that UV-B radiation is capable of causing considerable damage to living organisms, both in aquatic and terrestrial habitats (e.g. Nolan and Amanatidis, 1995; Lean, 1998). The most obvious consequence of the increasing UV-B radiation in aquatic environment is an often reported decrease in primary production (e.g. El Sayed, 1988; Häder et al., 1998). The abili-

\footnotetext{
*Received December 9, 1999. Accepted May 4, 2000.
}

ty of UV-B to produce free radicals of great oxidative power is well known (Halliwell and Gutteridge, 1989), and the effects induced by enhanced exposure to UV-B at the cellular level are therefore complex and often of considerable damage to living organisms (for review see Hessen et al., 1997). Even present day UV-B radiation induces stress both for phytoplankton and aquatic macroalgae (Häder, 1997; Häder et al., 1998). As pointed out by many authors, UV-B related responses among algae are individual and depend both on the physiological stage of the organism and environmental conditions (e.g. Xiong et al., 1996; Häder, 1997; Sundbäck et al., 1997). Various species of algae differ in their sensitivity to UV-B radiation. Taking this fact into 
account, changes in species composition depending on the UV-B doses can be expected (Cullen and Neale, 1994; Villafane et al., 1995; Helbling et al., 1996; Wängberg et al., 1996). Consequently, successions at the level of primary producers would undoubtedly affect higher trophic levels and thus cause changes in the entire aquatic ecosystem.

However, much more research is required in order to understand the role of UV-B within algal communities (Häder et al., 1998). Benthic and epiphytic algal communities in particular seem to be poorly understood in this sense. Only a few experimental studies with natural communities have been performed (Vinnebrooke and Leavitt,1996; Sundbäck et al., 1997; Odmark et al., 1998). Vinnebrooke and Leavitt (1996) are the only ones who have taken epilithic communities in alpine lakes under consideration as well. In this study we performed experiments in order to study dose-related responses to UV-B radiation within epilithic communities in brackish water. We hope that our study will contribute to a better understanding of this important part of aquatic ecosystems.

\section{MATERIALS AND METHODS}

The study was performed in June 1999 at the Department of Applied Science of Mid Sweden University in Härnösand, east coast of Sweden $\left(62^{\circ} 25^{\prime} 39 \mathrm{~N}, 17^{\circ} 23^{\prime} 17 \mathrm{E}\right)$. Five similar stones were sampled at the depth of $0.5 \mathrm{~m}$. The coastal area along Härnösand is tideless with brackish conditions (3.4-5.6\%o) and chlorophyll $a$ content of $2 \mathrm{mg} / \mathrm{m}^{3}$ during June (County Administration, Härnösand). All macroinvertebrates were carefully removed from the stones collected, after which the stones were placed in a 401 glass enclosure with artificial flow and aeration. All experiments were carried out at $23^{\circ} \mathrm{C}$. The light/dark cycle was $16 \mathrm{~h} / 8 \mathrm{~h}$ with an irradiance of $19 \mathrm{~W} \mathrm{~m}^{-2}$ (400-700 nm).

Epilithic communities were daily exposed to $1 \mathrm{~h}$, $3 \mathrm{~h}, 5 \mathrm{~h}$ or $7 \mathrm{~h}$ of UV radiation $(280-315 \mathrm{~nm})$, respectively. One stone served as control. The stones were irradiated by UV-A radiation $(315-400 \mathrm{~nm})$ of $1.02 \mathrm{~W} \mathrm{~m}^{-2}$ and UV-B radiation of $0.73 \mathrm{~W} \mathrm{~m}^{-2}$ at a distance of $0.35 \mathrm{~m}$ from the light source. UV-A and UV-B radiation were measured with an IL 1400A broad band Radiometer (International Light, Inc. Newburyport, MA) equipped with detectors for UVA (W\#6259, \#12667) and UV-B (W \#6272, \#12618). Ultraviolet radiation was obtained from two $40 \mathrm{~W}$ sunlamps (FS40, Westinghouse Elec. Corp. Lamp Div., Bloomfield, NJ, USA). The ultraviolet radiation was filtered through cellulose acetate (CA) film $(0.13 \mathrm{~mm}$ thickness $)$ in order to remove shorter wavelength components not encountered in nature. The CA was preburnt for $48 \mathrm{~h}$ at a distance of $1 \mathrm{~m}$ from $4 \mathrm{UV}$ lamps in order to minimize the change of the filter properties.

The experiments were repeated three times and carried out indoors in order to keep physical culture conditions constant. The duration of the study was set to 7 days in order to avoid possible later effects of nutrient depletion. Epilithic communities were studied before (initial stage, day 0) and after the experiments (day 7). On each occasion three samples from each stone were collected in order to identify algae species and analyze community structures. Epilithic species were identified with the aid of a wide range of literature, the most important being Pankow (1990). A rather traditional algal system was used for the classification of the taxa found (van den Hoek et al., 1995). The frequency of each species present in the fixed samples was determined according to a relative classification: 1 - occasional, 2 - rare, 3 - frequent, 4 - dominant. The reason for the use of relative abundance was its high applicability showed both for monitoring of successions and calculation of ecological indices (e.g. Kangas et al., 1993; Vinebrooke et al., 1996; Danilov and Ekelund, 2000).

Changes in species composition and community structure were estimated with the aid of two different approaches: multivariate method (cluster analysis) and ecological diversity indices (ShannonWiener's and Hurlbert's). Richness of each group was estimated with the aid of species number.

Diversity indices used:

1. Shannon-Wiener (Wiener, 1948; Shannon and Weaver, 1949):

$$
H^{\prime}=-\sum_{i=1}^{s} \frac{n_{i}}{n} \ln \frac{n_{i}}{n}
$$

$\mathrm{n}=$ the number of individuals in a sample from a population, $n_{i}=$ the number of individuals in a species $i$ of a sample from a population

2. Hurlbert's (Hurlbert, 1971) PIE (probability of interspecific encounters):

$$
P I E=\left(\frac{N}{N-1}\right)\left(1-\sum_{i=1}^{S} p_{i}^{2}\right)
$$

$\mathrm{N}=$ the number of individuals in a community, $\mathrm{p}_{\mathrm{i}}=$ the fraction of a sample of individuals belonging to species $i$. 
TABLE 1. - The list of epilithic species identified at the initial stage (I.s.) of the microcosm and on the seventh day after continuous treatment with UV-B radiation for $0,1,3,5$ and 7 hours/daily, respectively. The digits indicate relative abundance of each species present. Only correlation coefficients $(\mathrm{R})$ of the absolute value exceeding 0.1 are shown.

\begin{tabular}{|c|c|c|c|c|c|c|c|}
\hline Species & I. s. & $0 \mathrm{~h}$ & $1 \mathrm{~h}$ & $3 \mathrm{~h}$ & $5 \mathrm{~h}$ & $7 \mathrm{~h}$ & $\mathrm{R}$ \\
\hline \multicolumn{8}{|l|}{ CHLOROPHYCEAE } \\
\hline Cladophora sericea (Huds.) Kütz. & 0 & 0 & 3 & 2 & 2 & 2 & 0.33 \\
\hline Codiolum-stage & 1 & 0 & 2 & 1 & 1 & 1 & \\
\hline Hormiscia neglecta Kornmann & 0 & 0 & 1 & 0 & 0 & 0 & \\
\hline Monoraphidium contortum Kom.-Legn. & 0 & 4 & 2 & 1 & 2 & 2 & -0.49 \\
\hline Monoraphidium minutum (Näg.) Kom.-Legn. & 0 & 3 & 2 & 1 & 1 & 0 & -0.95 \\
\hline Pseudendoclonium marinum (Reinke) Aleem et Schulz & 4 & 2 & 2 & 4 & 2 & 2 & \\
\hline Ulothrix zonata (Weber et Mohr) Kütz. & 1 & 0 & 0 & 0 & 0 & 0 & \\
\hline \multicolumn{8}{|l|}{ CYANOPHYCEAE } \\
\hline Calothrix aeruginea (Kütz.) Thuret & 0 & 0 & 4 & 3 & 2 & 4 & 0.49 \\
\hline Oscillatoria amphibia C. A. Ag. & 0 & 0 & 0 & 3 & 4 & 4 & 0.93 \\
\hline Pseudanabaena mucicola Bourelly & 1 & 0 & 3 & 0 & 0 & 3 & 0.26 \\
\hline \multicolumn{8}{|l|}{ BACILLARIOPHYCEAE } \\
\hline Cocconeis pediculus Ehrenberg & 2 & 0 & 0 & 0 & 0 & 0 & \\
\hline Cymbella affinis Kütz. & 1 & 2 & 0 & 0 & 0 & 0 & -0.63 \\
\hline Epithemia argus (Ehrenberg) Kütz. & 1 & 1 & 0 & 0 & 1 & 0 & \\
\hline Fragilaria capucina Desmaz. & 4 & 2 & 2 & 0 & 1 & 0 & -0.79 \\
\hline Melosira varians C. A. Ag. & 1 & 1 & 0 & 0 & 1 & 0 & -0.22 \\
\hline Navicula spp. & 4 & 2 & 1 & 1 & 1 & 1 & -0.62 \\
\hline Opephora marina (Greg.) Petit & 3 & 2 & 1 & 0 & 0 & 0 & -0.84 \\
\hline Rhoicosphaenia abbreviata (C. A. Ag.) Lange-Bertalot & 4 & 1 & 3 & 0 & 1 & 0 & -0.57 \\
\hline Synedra ulna (Nitzsch) Ehrenberg. & 2 & 2 & 1 & 0 & 0 & 0 & -0.84 \\
\hline
\end{tabular}

In addition the number of species was used as a simple estimate of community structure. All statistical analyses were performed in the computer package Minitab 11.0.

\section{RESULTS AND DISCUSSION}

At the initial stage Chlorophyceae, Cyanophyceae and Bacillariophyceae were represented by two, one and eight unambiguously identified species, respectively (Table 1). The results obtained during all three repeated experiments did not show any differences. Navicula-species were considered as spp. due to the extreme difficulties in identifying all of them. However, insecure identification could lead to erroneous conclusions from statistical analyses. Therefore, Navicula was treated as a whole at the genus-level. Codiolum was considered not as a separate genus but as a stage of a filamentous green alga, supposingly Hormiscia neglecta. However, due to its physiological validity Codiolum-stage was considered by all statistical analyses performed. At the initial stage epilithic communities were dominated by Pseudendoclonium marinum and Bacillariophyceae. Cyanophyceae were under-represented both qualitatively and quantitatively.

After seven days two members of Chlorophyceae - Monoraphidium contortum and M. minutum - were the most abundant species in the control, while Codiolum-stage disappeared. No Cyanophyceae were found. All diatoms survived (except Cocconeis pediculus) but their abundance decreased.

In all treatments with UV-B Cyanophyceae became the most abundant group. All Cyanophyceae found were filamentous forms. Correlation between abundance of Cyanophyceae and the dose of UV-B radiation was positive for all three members (Table 1), although only slightly positive $(\mathrm{R}=0.26)$ for Pseudanabaena mucicola. This pattern agrees well with that detected for periphyton and epilithic communities in an alpine lake (Vinnebrooke and Leavitt, 1996). The dominance of filamentous forms of Cyanophyceae is also consistent with the results reported earlier (Vinnebrooke and Leavitt, 1996; Odmark et al., 1998). We can conclude that Cyanophyceae seem to outcompete other algae groups under enhanced UV-B radiation in epilithic communities as well as in benthos and periphyton.

Another phenomenon was appearance and increase in abundance (positive correlation, $\mathrm{R}=0.33$ ) of Cladophora sericea (Chlorophyceae) in all UV-B treated epilithic communities compared to the control. Monoraphidium contortum and M. minutum, being dominant in the control, were suppressed by all UV-B doses studied. Most of the diatoms correlated negatively with the increasing 


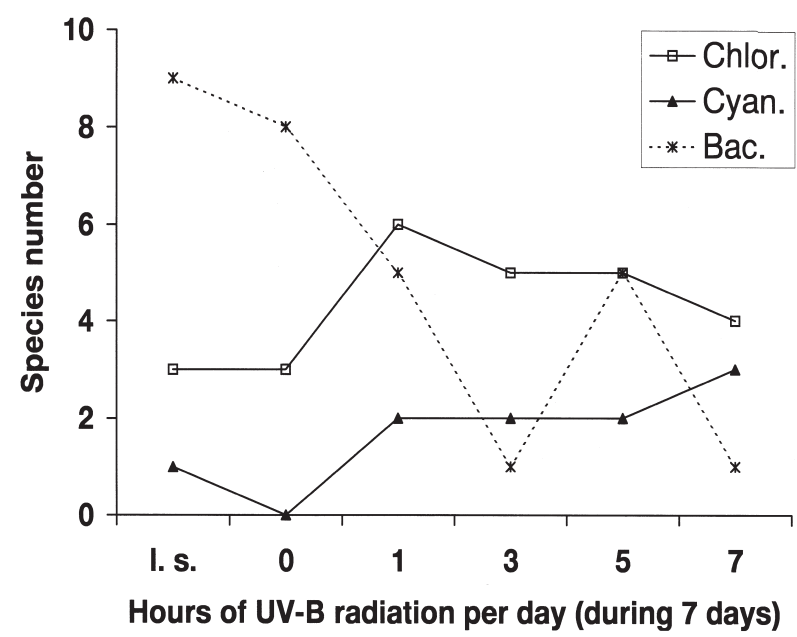

FIG. 1. - Changes in species richness of epilithic Chlorophyceae (Chlor.), Cyanophyceae (Cyan.) and Bacillariophyceae (Bac.) after continuous exposure to UV-B radiation for 0 (control), 1, 3, 5 and 7 hours/daily during 7 days. I.s. - initial stage of the microcosm.

UV-B doses ( $\mathrm{R}$ from - 0.22 to - 0.84 ). One of the possible explanations for the decrease in diatom abundance and richness and the suppressing of Monoraphidium contortum and $M$. minutum could be their relatively small size. There is evidence that small cells are more vulnerable to UV-B radiation than large cells (Laurion and Warwick, 1998). It has been shown that small diatoms became more damaged by UV-B than larger cells (Karentz et al., 1991). Therefore at the enhanced UV-B level a successions towards large cells can be expected. This pattern has been detected for diatoms in periphyton (Bothwell et al., 1993). In the present study, however, no such shifts have been observed. The diatom species present at the initial stage decreased considerably in their abundance or disappeared entirely (Fig. 1). However, the treatment for $5 \mathrm{~h}$ led to a sudden increase in the richness (but not in the abundance!) of Bacillariophyceae with the following drop at the treatment for $7 \mathrm{~h}$. We believe that this fact could be considered as an artefact because of the exclusively occasional detection (single exemplars, relative abundance 1) of the species. One possible reason for this could be some microscopic dif- ferences in the stone surfaces which enabled hiding of some exemplars of the diatoms.

However, the negative correlation to UV-B radiation observed for all diatoms in the present study disagrees with patterns observed for benthic communities on sandy sediment where under UVinduced stress diatoms codominated with cyanobacteria (Odmark et al., 1998). The epilithic communities in the present study responded quickly to UV-B treatment. No lag phase was observed as reported for sandy and periphytic communities (Bothwell et al., 1993, Odmark et al., 1998). Because of the experiment conditions used (see above) we believe that the patterns obtained were not additionally affected by nutrient limitation (Cullen and Lesser, 1991).

Negative effects of UV-B radiation on photosynthesis of algae are well known (e.g. Nielsen and Ekelund 1998), although sensitivity differs among species (Neale et al., 1998). UV-B radiation has been demonstrated to suppress growth and cell division (e.g. Keller et al., 1997). There is not much data about the individual sensitivity of periphytic algae to UV-B stress. The reason could be that the performance of experiments could differ between researchers, for example in UV-B doses and the wave spectrum of the radiation used. Therefore, it seems impossible to explain the patterns obtained in the present study, based on the published data on the sensitivity of different species. However, we suppose that the individual sensitivity to UV-B radiation of the species studied plays a key role in the succession observed.

The ecological indices calculated show a drop in diversity after $3 \mathrm{~h}$ exposure compared both to $1 \mathrm{~h}$, on the one hand, and to $5 \mathrm{~h}$ and $7 \mathrm{~h}$, on the other (Table 2). Diversity after $1 \mathrm{~h}$ and $5 \mathrm{~h}$ exposure was higher than in the control. It is generally believed that changing diversity of an aquatic community can be a good estimate of how favourable environmental conditions are (for review see e.g. Steneck and Dethier, 1994). If the increase in diversity observed after $5 \mathrm{~h}$ exposure to UV-B radiation should be viewed as artefact (see above), a slight decrease in

TABLE 2. - Diversity indices calculated for epilithic communities at the initial stage (I.s.) of the microcosm and on the seventh day after continuous treatment with UV-B radiation for $1,3,5$ or $7 \mathrm{~h} /$ day, respectively.

\begin{tabular}{lccccc}
\hline Index & I. s. & Control & $1 \mathrm{~h}$ & $3 \mathrm{~h}$ & $5 \mathrm{~h}$ \\
\hline Shannon-Wiener's & 2.32 & 2.31 & 2.47 & 1.93 & 2.37 \\
Hurlbert's & 0.92 & 0.93 & 0.94 & 0.89 & 0.94 \\
Species number & 13 & 11 & 13 & 0.90 \\
\end{tabular}




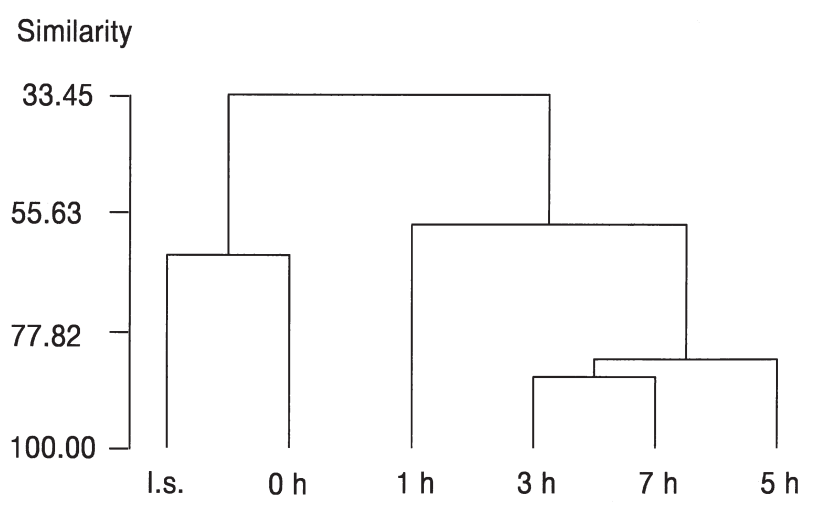

FIG. 2. - Cluster analysis of epilithic communities based on the presence-absence with abundance matrix: at the initial stage (I.s.) of the microcosm and on the seventh day in the control $(0 \mathrm{~h})$ and after continuous exposure to UV-B radiation during $1,3,5$ and 7 hours/daily.

diversity can be related to UV-B doses. However, we conclude that the shift in species composition was much more spectacular than the shift in diversity. Although we performed a relatively short-term study, changes in the structure of epilithic communities induced by the UV-B dose could be detected. Sundbäck et al. (1997) did not obtain any structural changes in benthic communities during a short-term experiment, which allows us to suppose that epilithic communities could be more vulnerable to UV-B radiation and therefore respond quicker than those on sandy sediments.

The multivariate cluster analysis based on the presence-absence with abundance matrix showed two large clusters: one built by the initial stage and control, and another consisting of the communities exposed to UV-B (Fig. 2). Thereby the communities which received higher doses of UV-B $(3 \mathrm{~h}, 5 \mathrm{~h}$ and $7 \mathrm{~h}$ ) are more closely related to each other than to the community treated for $1 \mathrm{~h}$ only. A possible explanation of this fact could be the specific sensitivity of individual species to UV-B stress mentioned above. We interpret the clustering of the control community together with the initial community as good evidence that the differences in patterns observed are directly related to the varying UV-B treatment.

\section{ACKNOWLEDGEMENTS}

We are grateful to the Mid Sweden University for the financial support of the present study and Andreas Eriksson for the proof-reading of the manuscript.

\section{REFERENCES}

Bothwell, M.L., D. Sherbot, A.C. Roberge and R.J. Daley. 1993. Influence of natural ultraviolet radiation on lotic periphytic diatom community growth, biomass accrual, and species composition: short-term versus long-term effects. $J$. Phycol., 29: 24-35.

Cullen, J.J. and M.P. Lesser. - 1991. Inhibition of photosynthesis by ultraviolet radiation as a function of dose and dosage rate: results for a marine diatom. Mar. Biol., 111: 183-190.

Cullen, J. and P. Neale. - 1994. Ultraviolet radiation, ozone depletion, and marine photosynthesis. Photosynth. Res., 39: 303-320.

Danilov, R.A. and N.G.A. Ekelund. - 2000. The use of epiphyton and epilithon data as base for calculating ecological indices in monitoring of eutrophication in lakes of central Sweden. Sci. Total. Envir., 248: 63-70.

El Sayed, S.Z. - 1988. Fragile life under the ozone hole. Natur. Hist., 97: 73-80.

Häder, D.-P. - 1997. Penetration and effect of solar UV-B on phytoplankton and macroalgae. Plant. Ecol., 128: 4-13.

Häder, D.-P., H.D. Kumar, R.C. Smith and R.C. Worrest. - 1998. Effects on aquatic ecosystems. J. Photochem. Photobiol. B, 46: 53-69.

Halliwell, B. and J.M.C. Gutteridge. - 1989. Free radicals in biology and medicine. 2nd ed., Clarendon Press, Oxford.

Helbling, E. W., B.E. Chalker, W.C. Dunlap, O. Holm-Hansen and V.E. Villafane. - 1996. Photoacclimation of Antarctic marine diatoms to solar ultraviolet radiation. J. Exp. Mar. Biology Ecol., 204: 85-101.

Hessen, D.O., H.J. De Lange and E. Van Donk. - 1997. UVinduced changes in phytoplankton cells and its effects on grazers. Freshwater Biol., 38: 513-524.

Hoek, van den C., D.G. Mann and H.M. Jahns. - 1995. Algae. Cambridge University Press, Cambridge.

Hurlbert, S. - 1971. The nonconcept of species diversity, a critique and alternative parameters. Ecology, 52: 577-586.

Kangas, P., E. Alasaarela, H. Lax, S. Jokela and C. Storgård-Envall. - 1993. Seasonal variation of primary production and nutrient concentrations in the coastal waters of the Bothnian Bay and the Quark. Aqua Fenn., 23: 165-176.

Karentz, K., F.S. McEuen, M.C. Land and W.C. Dunlap. - 1991. Survey of mycosporine-like amino acids in antarctic marine organisms: potential protection from ultraviolet exposure. Mar. Biol., 108: 157-166.

Keller, A.A., P. Hargraves, H. Jeon, G. Klein-MacPhee, E. Klos, C. Oviatt and J. Zhang. - 1997. Effects of ultraviolet-B enhancement on marine trophic levels in a stratified coastal system. Mar. Biol., 130: 227-287.

Laurion, I. and W.F. Vincent. - 1998. Cell size versus taxonomic composition as determinants of UV-sensitivity in natural phytoplankton communities. Limnol. Oceanogr., 43: 1774-1779.

Lean, D.R.S. - 1998. Influence of UVB radiation on aquatic ecosystems. In: E.E. Little, B.M. Greenberg and A.J. DeLonay (eds.), Environmental toxicology and risk assessment: seventh volume, pp. 1-20. ASTM, West Conshohocken, PA.

Neale, P.J., J.J. Cullen and R.F. Davis. - 1998. Inhibition of marine photosynthesis by ultraviolet radiation: variable sensitivity of phytoplankton in the Weddel-Scotia Confluence during the austral spring. Limnol. Oceanogr., 43: 433-448.

Nielsen, T. and N.G.A. Ekelund. - 1998. Inhibition and adaptation of photosynthesis in marine phytoplankton as an effect of ultraviolet radiation. In: C.V. Nolan and D.-P. Häder (eds.), Role of solar $U V-B$ radiation on ecosystems European commission ecosystems research report 30, pp. 87-99.

Nolan, C. and G. Amanatidis. - 1995. European Commission research on the fluxes and effects of environmental UVB radiation. J. Photochem. Photobiol. B, 31: 3-7.

Odmark, S., A. Wulff, S.-A. Wängberg, C. Nilsson and K. Sundbäck. - 1998. Effects of UVB radiation in a microbenthic community of a marine shallow-water sandy sediment. Mar. Biol., 132: 335-345.

Pankow, H. - 1990. Ostsee-Algenflora. Gustav Fischer Verlag, Jena.

Shannon, C.E. and W. Weaver. - 1949. The mathematical theory of communication. The University of Illinois Press, Urbana, IL.

Steneck, R.S. and M.N. Dethier. - 1994. A funktional-group approach to the structure of algal-dominated communities. Oikos, 69: 476-498. 
Sundbäck, K., S. Odmark, A. Wulff, C. Nilson and S.-Å. Wängberg. - 1997. Effects of enhanced UVB radiation on marine benthic diatom mat. Mar. Biol., 128: 171-179.

Villafane, V. E., E.W. Helbling, O. Holm-Hansen and B.E. Chalker. - 1995. Acclimatization of Antarctic natural phytoplankton assemblages when exposed to solar ultraviolet radiation. $J$. Plankton Res., 17: 2295-2306.

Vinnebrooke, R. and R. Leavitt. - 1996. Effects of ultraviolet radiation on periphyton in an alpine lake. Limnol. Oceanogr., 41: 1035-1040.

Wiener, N. - 1948. Cybernetics, or control and communication in the animal and the machine. The M.I.T. Press, Cambridge, MA. Wängberg, S. A., J.S. Selmer and K. Gustavson. - 1996. Effects of UV-B radiation on biomass and composition in marine phytoplankton communities. Sci. Mar., 60: 81-88.

Xiong, F., F. Lederer, J. Lukavsky and L. Nedbal. - 1996. Screening of freshwater algae (Chlorophyta, Chromophyta) for ultraviolet-B sensitivity of the photosynthetic apparatus. J. Plant Physiol., 148: 42-48.

Scient. ed.: M. Estrada 